\title{
Evaluation of sea mustard (Undaria pinnatifida) sporophylls from South Korea as fucoidan source and its corresponding antioxidant activities
}

\author{
Therese Ariane N. Neri ${ }^{1}$, Zuliyati Rohmah², Bernadeth F. Ticar ${ }^{3}$, Grace N. Palmos ${ }^{4}$ and Byeong-Dae Choi ${ }^{*}$ (DD
}

\begin{abstract}
Sporophylls from sea mustard, Undaria pinnatifida, which are by-products in seaweed production industries, were taken from Hansan Island, Tongyeong, and Gijang, Busan, and investigated for their fucoidan content and corresponding antioxidant activities. The extracted fucoidan yield from sporophylls of sea mustard samples from Tongyeong (TF) and Gijang (GF) were 12.1\% and 13.6\%, respectively. The antioxidant activities assessment of TF and GF extracts showed relative significant difference between samples, suggesting effect of location on bioactivities of fucoidan samples. GF was 50-68\% more effective than TF against DPPH and superoxide radicals samples which may be attributed to the difference in their degree of sulfation and monosaccharide composition. Meanwhile, TF exhibited greater scavenging activity against hydroxyl radicals compared to GF which could be due to protein impurities.
\end{abstract}

Keywords: Brown seaweed, Sea mustard, Undaria pinnatifida sporophyll, Fucoidan, Antioxidant activity

\section{Background}

With the advent of health awareness and health-conscious buyers, consumption of seaweeds and related goods has progressively increased in the market. Seaweeds are nutrient-rich food source mainly composed of proteins, amino acids, non-protein nitrogen, lipids, dietary fiber, vitamins, and minerals, as well as various bioactive compounds which are significant for biomedical, pharmaceutical, and health products. Bioactive compounds derived from seaweeds have been studied for anti-inflammatory, antiviral, anti-thrombic, and anticoagulant activities, anticancer and antitumor properties, anti-obesity, anti-diabetic, antihypertensive, and anti-hyperlipidemic capabilities (Bedoux et al. 2014; Smit 2004). However, the high demand in seaweed production has resulted to a substantial amount of by-products, which usually end up being dumped back to the ocean, during and after processing (Shi et al. 2019). One example of the commercially cultivated species is Undaria pinnatifida or sea mustards. From the family of

\footnotetext{
* Correspondence: bdchoi@gnu.ac.kr

${ }^{1}$ Department of Seafood Science and Technology/The Institute of Marine Industry, Gyeongsang National University, Tongyeong 53064, South Korea Full list of author information is available at the end of the article
}

brown seaweeds, and locally known as "Miyeok" in South Korea or "Wakame" in Japan, sea mustard is also considered a food commodity in China (Kim and Choi 1994). In seaweed processing industries, sea mustard by-products, such as sporophylls, are found to have essentially the same components to that of sea mustard, even after fermentation, and are examined as potential alternative nutrient source for broilers as animal feedstock (Shi et al. 2019).

Reactive oxygen species (ROS), which include superoxide $\left(\mathrm{O}_{2}^{-}\right)$and hydroxyl radicals $(\mathrm{OH})$, and hydrogen peroxides $\left(\mathrm{H}_{2} \mathrm{O}_{2}\right)$ are considered double-edged swords. While playing a crucial role in several biological functions such as intracellular messaging, cellular differentiation, growth arrestment, apoptosis, immunity, and defense against microorganisms, generated ROS may also exceed their antioxidant capacity, disrupt the redox balance, and, therefore, cause oxidative stress which, in turn, leads to cellular dysfunction. Oxidative stress takes a major part in the progression of some ailments like atherosclerosis, hypertension, aging, Alzheimer's disease, kidney malfunction, and even cancer (Roberts and Sindhu 2009), and accumulated evidence also supported the relationship of increased oxidative stress with 
diabetes and its complications (Henriksen et al. 2011). Antioxidant supplements have been reported to significantly reduce ROS generation and reinforce immune system defense, consequently preventing and delaying cell damage. Compared to synthetic counterparts, the public prefer natural antioxidants with minimum side effects due to growing health safety concerns (Nishibori et al. 2012). As a result, exploration of prospective antioxidants from plant and marine sources has become a trend, in the hopes of treating degenerative diseases.

Over the decades, fucoidan, a bioactive polysaccharide known for its antioxidant and other anti-proliferative activities, has been isolated from various brown seaweed species Ecklonia cava, Ascophylum nodusum, Laminaria japonica, and $U$. pinnatifida (Mak et al. 2013; Wang et al. 2009; Hu et al. 2010; Wijesinghe and Jeon 2012). In this study, we investigated fucoidan content from sporophylls of sea mustard from two different locations, Tongyeong and Gijang, in South Korea in order to promote utilization of by-products from Miyeok cultivation and processing, as potential bioactive compounds source, to develop health-related natural products. The isolated crude fucoidan extracts were tested for presence of fucose, protein residue, amino sugars, sulfate (sulfated glycans), and uronic acid and evaluated for antioxidant activities.

\section{Materials and methods}

Cultured sea mustards ( $U$. pinnatifida) were collected from the coastal areas of Hansan Island in Tongyeong (TF) and Gijang in Busan (GF), respectively. Sea mustard sporophylls were washed, drained of excess water, and airdried, protected from direct sunlight. The dried sporophylls were then pulverized using a grinder and kept in zip-locked bags at $-20^{\circ} \mathrm{C}$ until further analysis.

Chemical and radical reagents including 1,1-diphenyl-2picrylhydrazyl (DPPH), nicotinamide adenine dinucleotide $(\mathrm{NADH})$, nitro blue tetrazolium (NBT), phenazine methosulfate (PMS), ethylenediaminetetraacetic acid (EDTA), 1, 9-dimethylmethylene blue (DMMB), 3-methyl-2-benzothiazolinone hydrazine hydrochloride $(\mathrm{MBTH})$, and hydrogen peroxide $\left(\mathrm{H}_{2} \mathrm{O}_{2}\right)$ as well as fucoidan from Fucus vesiculosus, $\mathrm{D}$-galactose, bovine serum albumin (BSA), Lfucose, chondroitin-6-sulfate, N-acetyl-D-glucosamine, and D-glucuronic acid standards were all purchased from Sigma-Aldrich (St. Louis, MO, USA). Ascorbic acid and other reagents used were HPLC or analytical grade.

\section{Extraction, purification, and chemical composition of fucoidan}

Crude fucoidan was obtained using hot water extraction method by dispersing the defatted sea mustard sporophyll powder in distilled water $(1: 30 \mathrm{w} / \mathrm{w}$ ratio) with constant stirring for $3 \mathrm{~h}$ in a water bath at $80^{\circ} \mathrm{C}$. The solution was filtered and the filtrate was neutralized to pH 7.0 before adding anhydrous ethanol at a final concentration of $20 \%(\mathrm{v} / \mathrm{v})$ ethanol-filtrate mixture to separate alginic acid. The mixture was then centrifuged at $5376 \times g$ for $30 \mathrm{~min}$. The collected precipitate was dissolved in distilled water, dialyzed in deionized water for $48 \mathrm{~h}$ (MWCO $3600 \mathrm{Da}$ ), and lyophilized. The freezedried crude fucoidan was further purified by fractionation via anion-exchange chromatography method described by Mak et al. (2013) with minor modifications. Five grams of crude fucoidan was dissolved in $20 \mathrm{~mL}$ Tris- $\mathrm{HCl}$ buffer $(0.05 \mathrm{M}, \mathrm{pH} 7.4)$ and passed through a DEAE-Sephadex A-25 column $(2.6 \times 15 \mathrm{~cm})$, which is equilibrated with Tris- $\mathrm{HCl}$ buffer and connected to a fraction collector (Bio-Rad 2110, CA, USA). The first fraction was eluted with Tris- $\mathrm{HCl}$ buffer, followed by a step-wise elution with $0-2.0 \mathrm{M} \mathrm{NaCl}$ solution at a flowrate of $2 \mathrm{ml} / \mathrm{min}$ while eluates, were automatically collected at $4 \mathrm{ml}$ per tube. An aliquot from each eluted sample was checked for presence of sugars using phenol-sulfuric acid method by Dubois et al. (1956) to determine the changes in each elution. Elution was done until no more sugars were present. Carbohydratepositive fractions were then pooled together, dialyzed in deionized water for $48 \mathrm{~h}$ (MWCO $10.000 \mathrm{kDa}$ ), freezedried, and stored in air-tight containers for further use in succeeding antioxidant activity assays. The crude fucoidan extracts were evaluated for total sugar content, protein residue, fucose, sulfate, amino sugars, and uronic acids using the following methods, respectively: phenolsulfuric assay with D-galactose as standard (Dubois et al. 1956); Lowry method with BSA as standard; fucose determination with cysteine-sulfuric acid reaction; metachromasia assay with DMMB with chondroitin-6-sulfate as standard (Barbosa et al. 2003); MBTH assay with Nacetyl-D-glucosamine as standard (Tsuji et al. 1969); and carbazole assay with D-glucuronic acid as standard (Cesaretti et al. 2003).

\section{DPPH radical scavenging activity}

DPPH radical scavenging activity (RSA) of purified fucoidan extracts were analyzed according to slightly modified method by Shimada et al. (1992). Different concentrations $(0.01-1 \mathrm{mg} / \mathrm{mL})$ of sample and standard solutions were prepared in $40 \%$ methanol, and $4 \mathrm{~mL}$ aliquots were mixed with $1 \mathrm{ml}$ of $0.1 \mathrm{mM}$ methanolic $\mathrm{DPPH}$. The mixtures were shaken vigorously and allowed to stand in the dark at room temperature for 35 min. Absorbance was measured at $517 \mathrm{~nm}$. Ascorbic acid served as standard while $40 \%$ methanol was used as blank. Fucoidan standard (Sigma-Aldrich, St. Louis, MO, USA) was used as control for comparison. All determinations were performed in triplicate and DPPH RSA was computed using the following equation: DPPH radical 
scavenging activity $(\%)=1-\left(A / A_{0}\right) \times 100$, where $A$ and $A_{0}$ were the relative absorbances of DPPH solution with and without standard or sample added, respectively. Lower absorbance of reaction mixture indicated higher radical scavenging activity.

\section{Superoxide radical scavenging activity}

Superoxide RSA assay was performed based on method described by Nishikimi et al. (1972) with some adjustments. Superoxide radicals were generated in the PMS-NADH system of $3 \mathrm{~mL}$ Tris- $\mathrm{HCl}$ buffer $(16 \mathrm{mM}, \mathrm{pH} 8.0)$ containing $338 \mu \mathrm{M}$ NADH, $72 \mu \mathrm{M}$ NBT, $30 \mu \mathrm{M}$ PMS, and varying concentrations $(0.01-1 \mathrm{mg} / \mathrm{mL})$ of sample or standard solutions. The mixture was incubated at room temperature for $5 \mathrm{~min}$ and absorbance was read at $560 \mathrm{~nm}$ against Tris- $\mathrm{HCl}$ buffer as blank using microplate reader (Spectramax M2 Molecular Devices, Sunnyvale, CA, USA). Analysis was done in triplicates, and ascorbic acid was used as standard and fucoidan (Sigma-Aldrich, St. Louis, MO, USA) was used as control for comparison. Superoxide RSA was calculated using the following formula: Superoxide radical scavenging activity $(\%)=$ 1 - $\left(A / A_{0}\right) \times 100$, where $A$ and $A_{0}$ were the relative absorbances of radical solution with and without standard or sample added, respectively. Reaction mixture with lesser absorbance exhibited greater superoxide anion scavenging activity.

\section{Hydroxyl radical scavenging activity}

Hydroxyl RSA of extracted fucoidan from sea mustard was measured using a modified method by Smironoff and Cumbes (1989). An aliquot $(1 \mathrm{~mL})$ of sample and standard solutions with different concentrations (0.01-1 $\mathrm{mg} / \mathrm{mL}$ ) was mixed with $1 \mathrm{~mL}$ of sodium phosphate buffer $(0.15 \mathrm{M}, \mathrm{pH} 7.4)$ containing $10 \mathrm{mM} \mathrm{FeSO}_{4}, 10 \mathrm{mM}$ EDTA, and $2 \mathrm{mM}$ sodium salicylate and $1 \mathrm{ml}$ of $3 \%$ $\mathrm{H}_{2} \mathrm{O}_{2}$. The mixtures were incubated at $37^{\circ} \mathrm{C}$ for $30 \mathrm{~min}$, and absorbances were measured at $510 \mathrm{~nm}$. Analysis was done in triplicates and ascorbic acid was used as standard, and fucoidan (Sigma-Aldrich, St. Louis, MO, USA) was used as control for comparison. A sample blank was prepared by substituting sample solution with distilled water and replacing $\mathrm{H}_{2} \mathrm{O}_{2}$ with sodium phosphate buffer (0.15 M, pH 7.4). Hydroxyl RSA was estimated using the equation: Hydroxyl radical scavenging activity $(\%)=1$ - $\left(A / A_{0}\right) \times 100$, where $A$ and $A_{0}$ were the relative absorbances of sample and sample blank reaction mixtures, respectively.

\section{Statistical analysis}

All data were analyzed with analysis of variance using SAS software for Windows (SAS ver. 9.2, SAS Institute, Cary, NC, USA). Duncan's multiple-range test was used to detect significant differences $(p<0.05)$ between means $(n=3)$.

\section{Results and discussion}

\section{Sea mustard sporophyll's fucoidan content}

Brown seaweeds are rich in sulfated polysaccharides which are potential functional or nutraceutical ingredients. Seaweed-derived polysaccharides, including fucoidan, have been used in food, pharmaceutical, cosmetics, and other industries (Wijesinghe and Jeon 2012). The extracted fucoidan from sporophylls of sea mustard, $U$. pinnatifida, from Tongyeong (TF) and Gijang (GF) were $12.1 \%$ and $13.6 \%$, respectively. These results were slightly different from the study by Jeon et al. (2012), wherein they assessed 29 alga species and reported yields of $6.2 \%, 9.2 \%, 8.8 \%$, and $14.2 \%$ crude polysaccharide ethanolic extracts, for sporophyll of $U$. pinnatifida, $U$. pinnatifida, Sargassum fulvellum, and Sargassum thunbergii, accordingly, with higher yields (34.8\%, 30.8\%, and $30.6 \%$, respectively) for Dictyota dichotoma, Capsosiphon fulvescens, and Enteromorpha compressa.

Fucoidan content from seaweeds could vary from species to species, extraction method, geographical location, and seasonal variation (Rani et al. 2017). Aside from species variety, the extraction method used by Jeon et al. (2012) was not specific for fucoidan which could result to other compounds, such as alginic acid, to be included and affect the yield. In another study, Lee YK, Lim, Lee $\mathrm{YH}$, and Park (2006) investigated three cultivars of $U$. pinnatifida in Korea with a lower yield (1.0-3.8\%) of fucoidan extracts while higher but comparable data (13.71-26.34\%) was observed for the same species in New Zealand by Mak et al. (2013). Although similar species was used in these studies, the different fucoidan extraction yields may have resulted from different extraction methods utilized and geographical location of the samples. Lee et al. (2006) used dilute acid extraction method which could have affected the extraction rate due to fucoidan's reduced solubility at lower $\mathrm{pH}$ values while Mak et al. (2013) employed calcium chloride extraction.

Bioactive sulfated polysaccharides from brown seaweeds increasingly gained attention in scientific fields, particularly in pharmacology and biochemistry. Functional polysaccharides like fucans and alginic acid derivatives from brown seaweeds have demonstrated a variety of biological properties such as anticoagulant, antiinflammatory, antiviral, antitumor, and antioxidant activities (Wijesinghe and Jeon 2012). Additionally, antiapoptotic, anti-rheumatic, and anti-mutagenic properties of seaweeds were revealed to be mediated by their antioxidant activities (Choi et al. 2006). The crude fucoidan extracts were evaluated for total sugar, fucose, protein residue, amino sugars, sulfated glycans, and uronic acid content, as shown in Table 1.

Total sugar, fucose, protein residue, amino sugars, sulfate, and uronic acid content of fucoidan extract from 
Table 1 Chemical composition of crude fucoidan from sea mustard sporophylls

\begin{tabular}{lll}
\hline & TF & GF \\
\hline Total sugars $(\%)$ & $13.27 \pm 0.36$ & $13.39 \pm 0.36$ \\
Protein residue $(\%)$ & $1.15 \pm 0.04$ & $1.20 \pm 0.06$ \\
Fucose $(\mu \mathrm{g} / \mathrm{mg})$ & $285.57 \pm 1.73$ & $305.33 \pm 1.72$ \\
Sulfated glycans $(\mu \mathrm{g} / \mathrm{mg})$ & $708.16 \pm 1.75$ & $839.83 \pm 1.71$ \\
Amino sugars $(\mu \mathrm{g} / \mathrm{mg})$ & $253.94 \pm 1.06$ & $315.95 \pm 1.17$ \\
Uronic acid $(\mu \mathrm{g} / \mathrm{mg})$ & $402.13 \pm 1.53$ & $470.41 \pm 1.27$ \\
\hline Values are presented as mean $\pm \mathrm{SD}(n=3)$ &
\end{tabular}

Tongyeong was composed of $13.27 \%$ total sugar, $1.15 \%$ protein, $285.57 \mu \mathrm{g} / \mathrm{mg}$ fucose, $708.16 \mu \mathrm{g} / \mathrm{mg}$ sulfated glycans, $253.94 \mu \mathrm{g} / \mathrm{mg}$ amino sugar (hexosamines), and $402.13 \mu \mathrm{g} / \mathrm{mg}$ uronic acids. Meanwhile, components of GF were slightly higher (13.39\% total sugar, $1.20 \%$ protein, $305.33 \mu \mathrm{g} / \mathrm{mg}$ fucose, $839.83 \mu \mathrm{g} / \mathrm{mg}$ sulfated glycans, $315.95 \mu \mathrm{g} / \mathrm{mg}$ amino sugar (hexosamines), and $470.41 \mu \mathrm{g} / \mathrm{mg}$ uronic acids) than TF (13.27\% total sugar, $1.15 \%$ protein, $285.57 \mu \mathrm{g} / \mathrm{mg}$ fucose, $708.16 \mu \mathrm{g} / \mathrm{mg}$ sulfated glycans, $253.94 \mu \mathrm{g} / \mathrm{mg}$ amino sugar (hexosamines), and $402.13 \mu \mathrm{g} / \mathrm{mg}$ uronic acids). These data showed the heterogeneous nature of the composition of crude fucoidan extracted from both locations which were relatively comparable to the data in brown seaweed species reported by Mak et al. (2013), for U. pinnatifida, and Liu et al. (2016), for Sargassum pallidum. Additionally, the results confirmed presence of sulfated glycans with fucose residue in the crude extracts. Structural characteristics of fucoidan could be dependent on extraction technique, seaweed species, harvest season, geographical location, and algal maturity (Mak et al. 2013), which could explain the difference in data obtained from TF and GF samples. Presence of protein denoted the inherent nature of fucoidan to retain salts and protein which could be a part of the fucoidan structure or just a mere contaminant. Hayakawa and Nagamine (2009) suggested that pure fucoidan should have $0.1 \%$ or less of protein content; therefore, the fucoidan extracts in this study were in their crude forms. Nonetheless, these components influence the bioactivity of the fucoidan extracts from this study (Skriptsova et al. 2012).

DPPH radical scavenging activity of sea mustard fucoidan DPPH is a stable free radical, typically used to evaluate antioxidant capacity of bioactive compounds in different samples. Antioxidants with hydrogendonating capability reduce DPPH into a stable diamagnetic molecule, as indicated by the decrease in absorbance at $517 \mathrm{~nm}$ (Oktay et al. 2003). As shown in Fig. 1, the scavenging activity of sea mustard fucoidan extracts against DPPH radicals increase with increasing concentrations. DPPH RSA of GF was comparatively higher than $\mathrm{TF}$ at all concentrations. At $0.01 \mathrm{mg} / \mathrm{ml}, \mathrm{DPPH}$ RSA of both TF $(4.64 \%)$ and GF $(9.20 \%)$ were higher than the control fucoidan (2.78\%). However, as concentration of samples increased to $1 \mathrm{mg} / \mathrm{ml}$, DPPH RSA of control fucoidan (47.15\%) was higher than the crude fucoidan extracts (12.84\% and $21.47 \%$, respectively for TF and GF). Wang et al. (2009) observed similar results (5-25\% DPPH RSA at $0.5-4.0 \mathrm{mg} / \mathrm{ml}$ ) for synthesized fucoidan derivatives (oversulfated, acetylated, and benzoylated) from L. japonica from Qingdao, China. In addition, relatively comparable DPPH scavenging activities $(4-35 \%$ RSA at $0.2-1.4 \mathrm{mg} / \mathrm{ml})$ of desulfatedfucoidan fractions from $U$. pinnatifida, also from Qingdao, China, were reported by $\mathrm{Hu}$ et al. (2010). Meanwhile, fucoidan fractions from $U$. pinnatifida from New Zealand (Mak et al. 2013) exhibited higher, almost double, DPPH RSA than the observations in this study. This may be due to the variation in molecular weight, degree of sulfation, and monosaccharide composition influencing fucoidan's biological activities (Skriptsova et al. 2012). The fucoidan extracts from this study have molecular weights roughly $10.000 \mathrm{kDa}$, which is lower compared to the fucoidan fractions from $U$. pinnatifida from New Zealand (molecular weights ranging from 22 to $171 \mathrm{kDa}$ ), which may explain the higher DPPH RSA compared to TF and GF samples. $E C_{50}$, an indication of the effective concentration of the antioxidant to scavenge $50 \%$ of the radicals, of the crude fucoidan extracts were also computed. TF $(5.60 \mathrm{mg} / \mathrm{ml})$ was found to have higher $\mathrm{EC}_{50}$ than GF $(3.82 \mathrm{mg} / \mathrm{ml})$, which implied that GF was more effective than TF against DPPH radicals.

\section{Superoxide radical scavenging activity of sea mustard fucoidan}

Superoxide anions are considered predecessors of singlet oxygen, hydrogen peroxide, and hydroxyl radicals, thus, indirectly triggering lipid peroxidation, as well as magnifying oxidative cellular damage in lipids, proteins, and DNAs and further intensifying ailments such as arthritis and Alzheimer's disease (Wang et al. 2009). The scavenging ability of sea mustard fucoidan samples on superoxide radicals were examined in a concentration dependent manner (Fig. 2), and the same trend was observed as with DPPH RSA; superoxide RSA of TF and GF was significantly higher as concentration increased. GF exhibited a notable increase in superoxide RSA from $0.1 \mathrm{mg} / \mathrm{ml} \mathrm{(29.3 \% )} \mathrm{to} 1 \mathrm{mg} / \mathrm{ml}$ (39.2\%) with $\mathrm{EC}_{50}$ value of $1.63 \mathrm{mg} / \mathrm{ml}$. Meanwhile, TF demonstrated superoxide RSA of $22.6 \%$ at $0.1 \mathrm{mg} / \mathrm{ml}$ and $26.8 \%$ at $1 \mathrm{mg} / \mathrm{ml}$ with $\mathrm{EC}_{50}$ of $3.22 \mathrm{mg} / \mathrm{ml}$. These results are slightly lower but almost similar to the data reported by $\mathrm{Hu}$ et al. (2010), which range from 10 to $45 \%$ RSA at $0.6-1.6 \mathrm{mg} / \mathrm{ml}$ of $U$. 


\section{DPPH Radical Scavenging Activity}

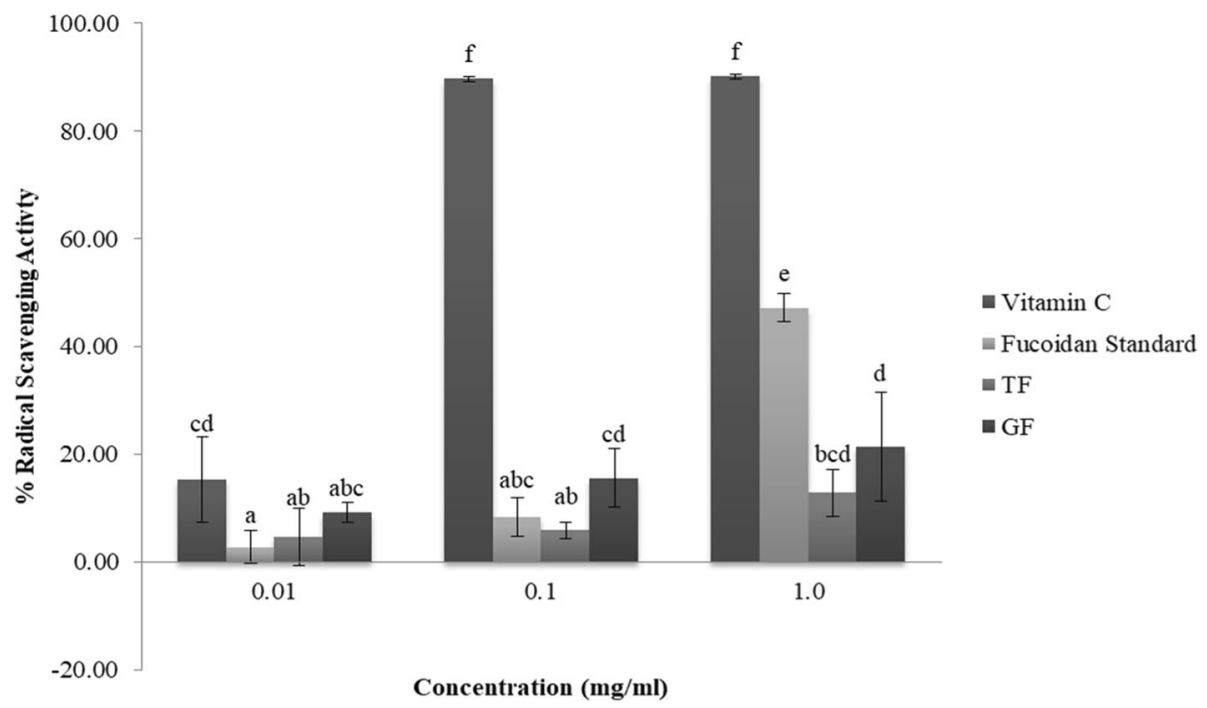

Fig. 1 DPPH radical scavenging activity of sea mustard-derived fucoidan. Data presented as means $\pm \operatorname{SD}(n=3)$. Bars with different superscripts significantly vary from each other $(p<0.05)$

pinnatifida fucoidan extract from China. TF and GF were detected to have greater inhibitory effect on superoxide than DPPH radicals, as displayed by their $\mathrm{EC}_{50}$ values. This could be due to superoxide anions being relatively weaker oxidants compared to DPPH and other radicals (Wang et al. 2009). Based on the resulting $E_{50}$, GF exhibited greater scavenging ability against superoxide radicals than TF, which may be credited to the higher sulfated glycan contents in GF $(839.83 \mu \mathrm{g} / \mathrm{mg})$ compared to TF $(708.16 \mu \mathrm{g} / \mathrm{mg})$ as electron-donating constituents (like sulfate groups) increase RSA (Wang et al. 2009).

\section{Hydroxyl radical scavenging activity of sea mustard} fucoidan

Hydroxyl radicals, $\mathrm{OH}$, are the most active and potent among reactive oxygen species which cause severe damage to neighboring biomolecules like carbohydrates, proteins, lipids, and nucleic acids and initiate aging, cancer, and other degenerative diseases (Chung et al. 1997). Hence, inhibiting or scavenging hydroxyl radicals is vital for antioxidant defense. TF and GF hydroxyl radical scavenging activity were also evaluated in a concentration-dependent manner (Fig. 3). As the concentration increased, TF and GF samples showed greater hydroxyl RSA (TF: 8.4\%,

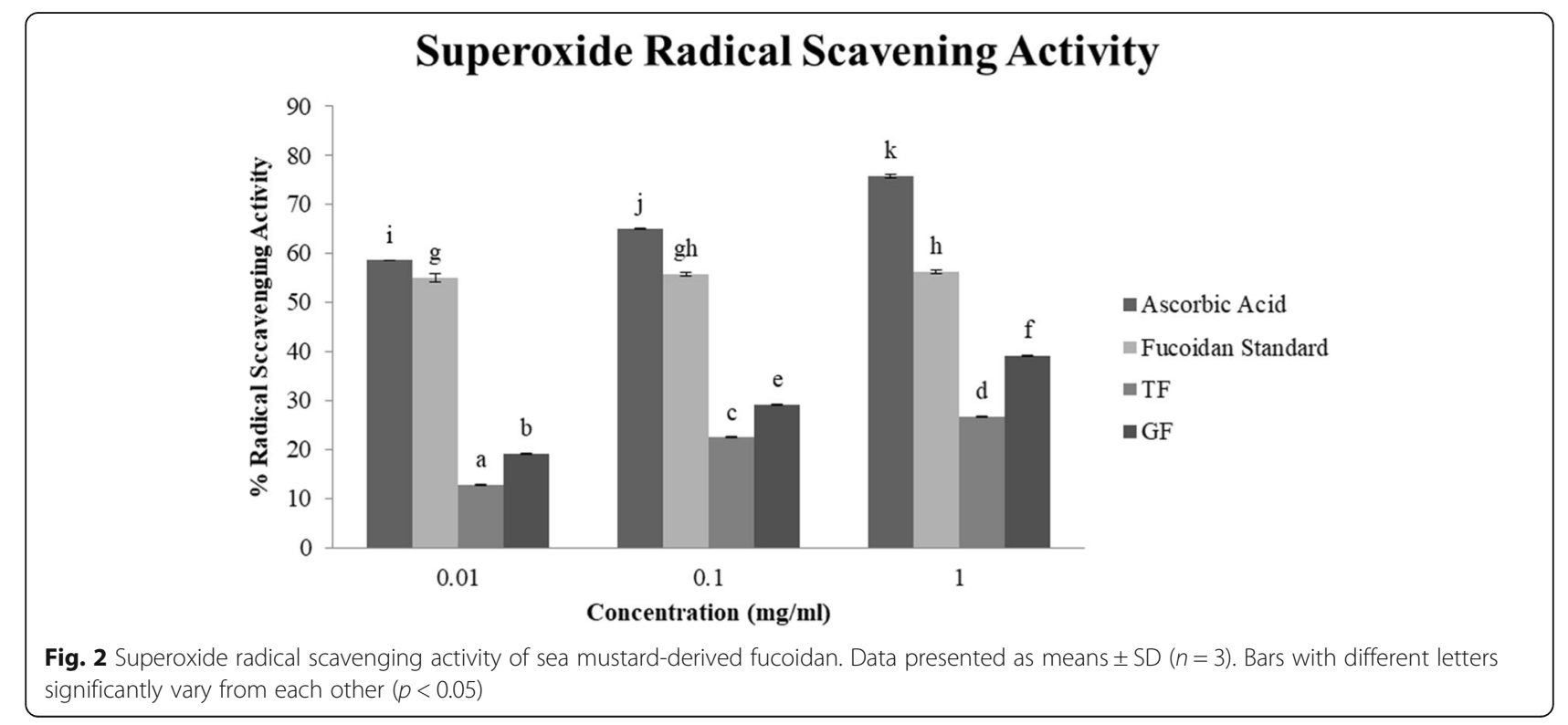




\section{Hydroxyl Radical Scavenging Activity}

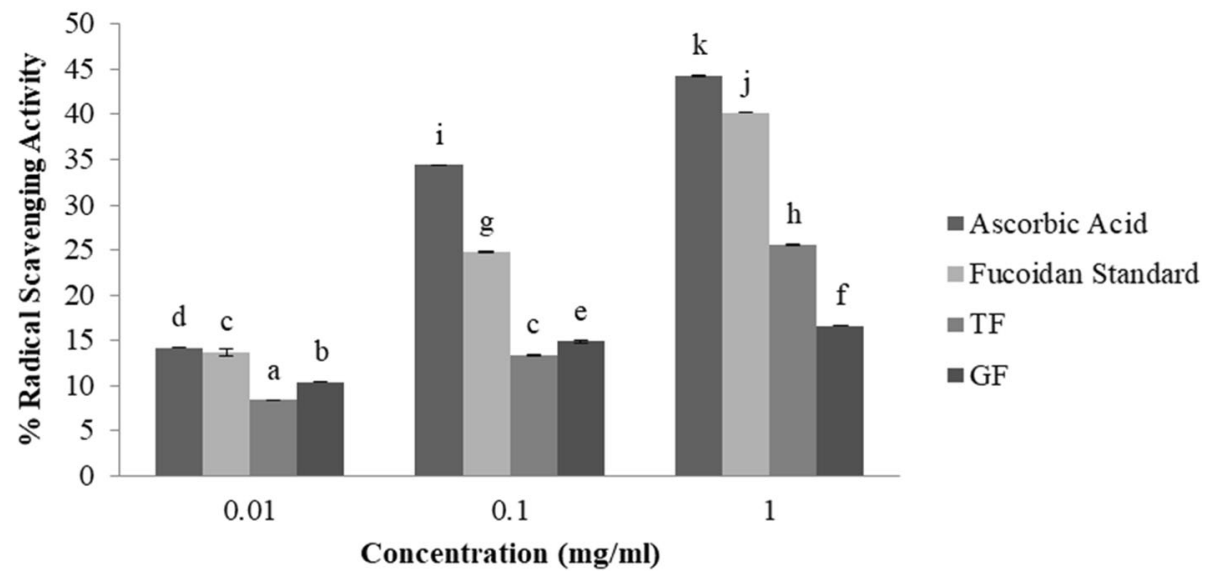

Fig. 3 Hydroxyl radical scavenging activity of sea mustard-derived fucoidan. Data presented as means \pm SD $(n=3)$. Bars with different letters significantly vary from each other $(p<0.05)$

$13.4 \%$, and $25.6 \%$, and GF: $10.4 \%$, $14.9 \%$, and $16.6 \%$, respectively, at $0.01 \mathrm{mg} / \mathrm{ml}, 0.1 \mathrm{mg} / \mathrm{ml}$, and $1 \mathrm{mg} / \mathrm{ml})$. These results were more or less the same to the hydroxyl RSA of crude fucoidan extracted from L. japonica (5-20\% RSA at $0.5-2.10 \mathrm{mg} / \mathrm{ml}$ ) from Qingdao, China (Wang et al. 2009), and moderately lower than that of $U$. pinnatifida (12-35\% RSA at $0.6-1.2 \mathrm{mg} / \mathrm{ml}$ ), also from China (Hu et al. 2010). Previous studies reported two types of antioxidant mechanism: inhibiting hydroxyl radical generation by formation of metals complexes and scavenging the hydroxyl radicals generated which is related to iron chelating ability (Shon et al. 2003). The observed hydroxyl radical RSA of TF and GF were lower than the control fucoidan $(13.7 \%, 24.8 \%$, and $40.2 \%$, accordingly, at $0.01 \mathrm{mg} / \mathrm{ml}, 0.1 \mathrm{mg} / \mathrm{ml}$, and 1 $\mathrm{mg} / \mathrm{ml}$ ). Moreover, TF $\left(\mathrm{EC}_{50}: 2.53 \mathrm{mg} / \mathrm{ml}\right.$ ) was found to be more effective against hydroxyl radicals than $\mathrm{GF}\left(\mathrm{EC}_{50}\right.$ : $8.40 \mathrm{mg} / \mathrm{ml}$ ) which could be due to the protein impurities in the extracts. GF (1.20\%) was found to have slightly higher protein residue than TF $(1.15 \%)$ which could have interfered with their hydroxyl RSA.

\section{Conclusions}

Fucoidan extracted from sea mustard sporophylls from Tongyeong (TF) and Gijang City (GF) both demonstrated lower scavenging activity on DPPH, superoxide, and hydroxyl radicals when compared with ascorbic acid as positive control and pure fucoidan standard as sample control. This could be caused by the impurities present in the crude fucoidan extracted in this study which was supported by the presence of protein residue greater than $0.1 \%$. GF had greater total sugar, fucose, amino sugar, sulfated glycans, and uronic acids content than TF which resulted to GF exhibiting higher RSA against DPPH and superoxide radical. On the other hand, TF displayed higher RSA than GF against hydroxyl radical only which could be caused by greater interfering protein impurities in GF. Further characterization (structure elucidation) and derivatization (acetylation, sulfation, etc.) is recommended to identify the mechanism of antioxidant action in each sample which may improve corresponding bioactivities of TF and GF. Although the crude fucoidan extracts in this study, TF and GF, exhibited lower antioxidant activities compared to ascorbic acid and pure fucoidan, the results showed a prospect of utilizing/exploiting sea mustard sporophylls, which are byproducts in seaweed processing,

\section{Abbreviations}

BSA: Bovine serum albumin; DEAE: Diethylaminoethyl; DMMB: 1,9dimethylmethylene blue; DPPH: 1,1-diphenyl-2-picrylhydrazyl;

EDTA: Ethylenediaminetetraacetic acid; GF: Gijang fucoidan; MBTH: 3-methyl2-benzothiazolinone hydrazine hydrochloride; MWCO: Molecular weight cutoff; NADH: Nicotinamide adenine dinucleotide; NBT: Nitro blue tetrazolium; PMS: Phenazine methosulfate; ROS: Reactive oxygen species; RSA: Radical scavenging activity; TF: Tongyeong fucoidan

Acknowledgements

Not applicable.

Authors' contributions

All authors helped in the conceptualization of the design and implementation of this study and they have read and approved the final manuscript.

Funding

Not applicable.

Availability of data and materials

Please contact author for data requests.

Ethics approval and consent to participate Not applicable.

Consent for publication

Not applicable. 


\section{Competing interests}

The authors declare that they have no competing interests.

\section{Author details}

'Department of Seafood Science and Technology/The Institute of Marine Industry, Gyeongsang National University, Tongyeong 53064, South Korea. ${ }^{2}$ Faculty of Biology, Universitas Gadjah Mada, Yogyakarta 55281, Indonesia. ${ }^{3}$ Natural Science Department, College of Arts and Sciences, lloilo Science and Technology University, 5000 Iloilo, Philippines. ${ }^{4}$ Institute of Fish Processing Technology, University of the Philippines Visayas, Miagao, 5023 Iloilo, Philippines.

Received: 28 May 2019 Accepted: 31 October 2019 Published online: 19 November 2019

\section{References}

Barbosa I, Garcia S, Barbier-Chassefiere V, Caruelle JP, Martelly I, papy-Garcia D. Improved and simple micro assay for sulfated glycosaminoglycans quantification in biological extracts and its use in skin and muscle tissue studies. Glycobiology. 2003;13(9):647-53. https://doi.org/10.1093/glycob/ cwg082.

Bedoux G, Hardouin K, Burlot AS, Bourgougnon N. Bioactive components from seaweeds: cosmetic applications and future development. Adv Bot Res. 2014; 71:345-78. https://doi.org/10.1016/B978-0-12-408062-1.00012-3.

Cesaretti M, Luppi E, Maccari F, Volpi N. A 96-well assay for uronic acid carbazole reaction. Carbohydr Polym. 2003;54(1):59-61. https://doi.org/10.1016/S01448617(03)00144-9.

Choi SY, Kim SY, Hur JM, Choi HG, Sung NJ. Antioxidant activity of solvent extracts from Sargassum thunbergii. J Korean Soc Food Sci Nutr. 2006;35(2): 139-44 Retrieved from http://jkfn.kfn.or.kr/archive/index.html?gubun= $3 \&$ year $=2006 \& \mathrm{vol}=35 \& \mathrm{ho}=2 \& \mathrm{ifv}=1$.

Chung SK, Osawa T, Kawakishi S. Hydroxyl radical-scavenging effects of spices and scavengers from brown mustard (Brassica nigra). Biosci Biotechnol Biochem. 1997;61(1):118-23. https://doi.org/10.1271/bbb.61.118.

Dubois M, Gilles K, Hamilton J, Rebers P, Smith F. Colorimetric method for determination of sugars and related substances. Anal Chem. 1956;28(3):3506. https://doi.org/10.1021/ac60111a017.

Hayakawa K, Nagamine T. Effect of fucoidan on the biotinidase kinetics in human hepatocellular carcinoma. Anticancer Res. 2009:29(4):1211-7.

Henriksen EJ, Diamond-Stanic MK, Marchionne EM. Oxidative stress and the etiology of insulin resistance and type 2 diabetes. Free Radic Biol Med. 2011; 51(5):993-9. https://doi.org/10.1016/j.freeradbiomed.2010.12.005.

Hu T, Liu D, Chen Y, Wu J, Wang S. Antioxidant activity of sulfated polysaccharide fractions extracted from Undaria pinnitafida in vitro. Int J Biol Macromol. 2010;46(2):193-8. https://doi.org/10.1016/j.jibiomac.2009.12.004.

Jeon YE, Yin XF, Lim SS, Chung CK, Kang IJ. Antioxidant activities and acetylcholinesterase inhibitory activities from seaweed extracts. J Korean Soc Food Sci Nutr. 2012;41(4):443-9 Retrieved from http://jkfn.kfn.or.kr/archive/ index.html?gubun $=3 \& y$ ear $=2012 \& \mathrm{vol}=41 \& \mathrm{ho}=4 \& \mathrm{ifv}=1$.

Kim WJ, Choi HS. Development of combined methods for effective extraction of sea mustard. Korean J Food Sci Technol. 1994;26(1):44-50 Retrieved from http://www.kffst.or.kr/journal/view.html?uid=3149\&page =\&sort=\&scale= 10\&all_k=\&s_t=\&s_a=\&s_k=\&s_v=26\&s_n=1\&spage =\&pn=search\&year = \&vmd=Full.

Lee YK, Lim DJ, Lee YH and Park YI. Variation in Fucoidan Contents and Monosaccharide Compositions of Korean Undaria pinnatifida (Harvey). Suringar (Phaeophyta). Algae. 2006;21(1):157-160.

Liu X, Liu B, Wie XL, Sun ZL and Wang CY. Extraction, Fractionation, and Chemical Characterisation of Fucoidans from the Brown Seaweed Sargassum pallidum. Czech J Food Sci, 2016;34(5):406-413. https://doi.org/10.1 7221/322/2015-CJFS.

Mak W, Hamid N, Liu T, Lu J, White WL. Fucoidan from New Zealand Undaria pinnatifida: monthly variations and determination of antioxidant activities. Carbohydr Polym. 2013;95(1):606-14. https://doi.org/10.1016/j.carbpol.2013. 02.047

Nishibori N, Sagara T, Hiroi T, Sawaguchi M, Itoh M, Her S, Morita K. Protective effect of Undaria pinnatifida sporophyll extract on iron induced cytotoxicity and oxidative stress in PC12 neuronal cells. Phytopharmacology. 2012;2(2): 271-84 Retrieved from http://inforesights.com/phytopharmacology/files/pp2 v2i13.pdf.
Nishikimi M, Rao NA, Yagi K. The occurrence of superoxide anion in the reaction of reduced phenazine methosulfate and molecular oxygen. Biochem Biophys Res Commun. 1972;46(2):849-54. https://doi.org/10.1016/50006291X(72)80218-3.

Oktay M, Gülçin I, Küfrevioğlu Ö. Determination of in vitro antioxidant activity of fennel (Foeniculum vulgare) seed extracts. LWT Food Sci Technol. 2003;36(2): 263-71. https://doi.org/10.1016/S0023-6438(02)00226-8.

Rani V, Shakila RJ, Jawahar P, Srinivasan A. Influence of species, geographic location, seasonal variation and extraction method on the fucoidan yield of the brown seaweeds of Gulf of Mannar, India. Indian J Pharm Sci. 2017;79(1): 65-71. https://doi.org/10.4172/pharmaceutical-sciences.1000202.

Roberts CK, Sindhu KK. Oxidative stress and metabolic syndrome. Life Sci. 2009; 84(21-22):705-12. https://doi.org/10.1016/j.lfs.2009.02.026.

Shi H, Kim SH, Kim IH. Effect of dietary inclusion of fermented sea mustard byproducts on growth performance, blood profiles, and meat quality in broilers. J Sci Food Agric. 2019;99(9):4304-8. https://doi.org/10.1002/jsfa.9663.

Shimada K, Fujikawa K, Yahara K, Nakamura T. Antioxidative properties of xanthan on the autoxidation of soybean oil in cyclodextrin emulsion. J Agric Food Chem. 1992;40(6):945-8. https://doi.org/10.1021/jf00018a005.

Shon MY, Kim TH, Sung NK. Antioxidants and free radical scavenging activity of Phellinus baumii (Phellinus of Hymenochaetaceae) extracts. Food Chem. 2003; 82(4):593-7. https://doi.org/10.1016/50308-8146(03)00015-3.

Skriptsova AV, Shevchenko NM, Tarbeeva DV, Zvyagintseva TN. Comparative study of polysaccharides from reproductive and sterile tissue of five brown seaweeds. Mar Biotechnol. 2012;14(3):304-11. https://doi.org/10.1007/s10126011-9413-4.

Smironoff N, Cumbes Q. Hydroxyl radical scavenging activity of compatible solutes. Phytochemistry. 1989;28(4):1057-60. https://doi.org/10.1016/00319422(89)80182-7.

Smit AJ. Medicinal and pharmaceutical uses of seaweed natural products: a review. J Appl Phycol. 2004;16(4):245-62. https://doi.org/10.1023/B:JAPH. 0000047783.36600.ef.

Tsuji A, Kinoshita T, Hoshino M. Analytical chemical studies on amino sugars. II. Determination of Hexosamines using 3-Methyl-2-benzothiazolinone Hydrazone Hydrochloride. Chem Pharm Bull. 1969;17(7):1505-10. https://doi. org/10.1248/cpb.17.1505.

Wang J, Liu L, Zhang Q, Zhang Z, Qi H, Li P. Synthesized oversulphated, acetylated and benzoylated derivatives of fucoidan extracted from Laminaria japonica and their potential antioxidant activity in vitro. Food Chem. 2009; 114(4):1285-90. https://doi.org/10.1016/j.foodchem.2008.10.082.

Wijesinghe WAJP, Jeon YJ. Biological activities and potential industrial applications of fucose rich sulfated polysaccharides and fucoidans isolated from brown seaweeds: a review. Carbohydr Polym. 2012;88(1):13-20. https:// doi.org/10.1016/j.carbpol.2011.12.029.

\section{Publisher's Note}

Springer Nature remains neutral with regard to jurisdictional claims in published maps and institutional affiliations.
Ready to submit your research? Choose BMC and benefit from:
- fast, convenient online submission
- thorough peer review by experienced researchers in your field
- rapid publication on acceptance
- support for research data, including large and complex data types
- gold Open Access which fosters wider collaboration and increased citations
- maximum visibility for your research: over $100 \mathrm{M}$ website views per year
At BMC, research is always in progress.
Learn more biomedcentral.com/submissions 